\title{
PERBEDAAN NILAI LEUKOSIT PRA- DAN PASCAOPERASI SEBAGAI PREDIKTOR LUARAN FUNGSIONAL PERDARAHAN INTRASEREBRAL SPONTAN
}

\author{
DIFFERENCES BETWEEN PRE-AND POST-SURGERY LEUKOCYTE \\ COUNTS AS FUNCTIONAL OUTCOME PREDICTOR IN SPONTANEOUS \\ INTRACEREBRAL HEMORRHAGE
}

\author{
Hanif Gordang Tobing, * Bismo Nugroho PPR, * Mohamad Saekhu, * Setyo Widi Nugroho, * Affan Priyambodo, * \\ Wismaji Sadewo, * Syaiful Ichwan, * Renindra Ananda Aman, * David Tandian, * Samsul Ashari*
}

\section{ABSTRACT}

Introduction: Hematoma in spontaneous intra-cerebral hemorrhage (SICH) results inflammation due to secondary brain injury. Leukocyte, an inflammation indicator which is routinely examined, known as an outcome predictor in nonoperated SICH. The role of inflammation in operated SICH is still unknown, however, pre- and post-surgery leukocyte counts can be a marker of brain tissue damage (brain injury).

Aim: This study investigated the characteristics of leucocyte parameters in operated SICH patients and its correlation to functional outcome based on Glasgow Outcome Scale (GOS).

Methods: This was a retrospective cohort study for SICH patients who underwent surgery at Department of Neurosurgery in Dr. Cipto Mangunkusumo National General Hospital from January 2012-March 2017. This study analyzed the association between pre-operative leucocyte level with age, pre-operative GCS, hemorrhage volume, length of hospitalization, and six-month post-operative GOS. The correlation of differences of pre-operative and one-day postoperative leucocyte counts with six-month post-operative GOS and hematoma evacuation percentage were analyzed. The analysis was done using Pearson correlation test, Spearman, Chi-square $\chi^{2}$ test, Fisher exact test, and Anova test.

Results: There was a significant correlation between differences of leukocyte counts in pre- and post-surgery with GOS. A higher post-surgery leukocyte difference would lower GOS; there was a significant correlation between the leukocytes counts in pre-operative leucocyte and GCS. A higher pre-operative leukocytes counts would lower the GCS.

Discussion: The differences of pre-operative and post-operative leucocyte counts is a functional outcome predictors within 6 months in operated SICH patients.

Keywords: Leukocyte, outcome, spontaneous intracerebral hemorrage, surgery

\section{ABSTRAK}

Pendahuluan: Hematoma pada perdarahan intraserebral spontan (PISS) menyebabkan inflamasi akibat cedera otak sekunder. Leukosit sebagai indikator inflamasi yang rutin diperiksa, diketahui memiliki peranan sebagai prediktor luaran pada PISS yang tidak dioperasi. Sejauh ini belum diketahui peranan inflamasi pada PISS yang dioperasi, namun kadar leukosit pra- dan pascaoperasi dapat menjadi penanda adanya kerusakan jaringan otak (brain injury).

Tujuan: Untuk mengetahui karakteristik parameter leukosit pasien PISS yang dioperasi dan kaitannya dengan luaran fungsional berdasarkan skor Glasgow Outcome Scale (GOS).

Metode: Studi kohort retrospektif pada pasien PISS yang dioperasi di Departemen Bedah Saraf RSUPN Dr. Cipto Mangunkusumo periode Januari 2012-Maret 2017. Dilakukan analisis antara nilai leukosit praoperasi dengan usia, GCS praoperasi, volume perdarahan, lama rawat inap, dan skor GOS 6 bulan pascaoperasi. Dilakukan analisis perbedaan nilai leukosit praoperasi dibandingkan hari pertama pascaoperasi dengan skor GOS 6 bulan pascaoperasi dan persentase evakuasi hematoma. Analisis dilakukan menggunakan korelasi Pearson, Spearman, uji Chi-square $\chi^{2}$ test, Uji Fisher exact test, dan Anova.

Hasil: Pada uji statistik didapatkan korelasi bermakna antara perbedaan nilai leukosit pascaoperasi dibandingkan praoperasi dengan skor GOS. Semakin tinggi nilai perbedaan leukosit pascaoperasi akan menurunkan skor GOS; didapatkan korelasi bermakna antara leukosit praoperasi dengan GCS praoperasi. Semakin tinggi leukosit praoperasi, semakin rendah GCS.

Diskusi: Perbedaan nilai leukosit pascaoperasi dibandingkan praoperasi merupakan prediktor luaran fungsional dalam 6 bulan pada pasien perdarahan intraserebral spontan yang dioperasi.

Kata kunci: Leukosit, luaran, operasi, perdarahan intraserebral spontan

*Departemen Bedah Saraf FK Universitas Indonesia/RSUPN Dr. Cipto Mangunkusumo, Jakarta. Korespondensi: bismonugrohoppr@ gmail.com. 


\section{PENDAHULUAN}

Perdarahan intraserebral spontan (PISS) memiliki prevalensi sebanyak $4-14 \%$ dari seluruh stroke di seluruh dunia dan merupakan kondisi serius dalam bedah saraf karena memiliki angka mortalitas dan morbiditas yang tinggi. Rasio kematian pada 1 bulan setelah onset PISS tidak berubah selama beberapa dekade terakhir, yaitu sebesar 25-35\% pada negara maju dan 30-48\% pada negara berkembang. Hanya sebanyak 20\% dari seluruh kasus yang dapat menjadi individu yang independen pada enam bulan pasca-awitan. ${ }^{1-2}$

Perdarahan intraserebral spontan menyebabkan terjadinya cedera otak primer akibat kerusakan jaringan otak mekanik dan efek desak ruang terhadap jaringan sekitar, serta cedera otak sekunder akibat proses inflamasi dari produk degradasi hematoma dan kerusakan jaringan. ${ }^{3}$ Diketahui adanya peran inflamasi pada patofisiologi PISS, ${ }^{4-5}$ dengan adanya peningkatan penanda inflamasi akut pada kerusakan otak (brain injury), antara lain nilai leukosit. ${ }^{2}$

Leukosit merupakan salah satu penanda inflamasi yang rutin, mudah, dan murah untuk diperiksa. Pada pasien PISS yang tidak dioperasi, nilai leukosit berkaitan signifikan dengan derajat keparahan PISS, deteriorasi neurologis awal, luaran buruk dalam 3 bulan, dan angka mortalitas jangka panjang. ${ }^{6-7}$ Perbedaan nilai leukosit dalam 72 jam dapat lebih baik merefleksikan derajat respons inflamasi pada PISS yang tidak dioperasi dan memprediksi luaran fungsional yang buruk dalam 3 bulan. ${ }^{4}$ Namun hingga saat ini belum diketahui peran leukosit pada pasien PISS yang dioperasi dan kaitannya dengan luaran.

Luaran pasien PISS sangat berkaitan dengan faktor prognostik yang telah diketahui dan dapat dinilai, seperti volume dan ekspansi hematoma, Glasgow Coma Scale (GCS) saat admisi, adanya pergeseran garis tengah (midline shift), perdarahan intraventrikel, nilai fibrinogen, dan D-dimer. ${ }^{3,8-9}$ Dibutuhkan prediksi luaran yang akurat pada pasien PISS yang dioperasi untuk membedakan pasien yang akan memiliki manfaat dari tata laksana yang dilakukan, sehingga dapat ditentukan prognosis dan tujuan rehabilitasi yang akurat. ${ }^{8,10}$

\section{TUJUAN}

Untuk mengetahui karakteristik parameter leukosit pasien PISS yang dioperasi dan kaitannya dengan luaran fungsional berdasarkan Glasgow Outcome Scale (GOS).

\section{METODE}

Studi kohort retrospektif terhadap pasien PISS yang dioperasi di Departemen Bedah Saraf RSUPN Dr. Cipto Mangunkusumo (RSCM) selama periode Januari 2012 hingga Maret 2017. Kriteria inklusi adalah pasien yang menjalani operasi kurang dari 72 jam onset PISS. Kriteria eksklusi adalah PISS akibat trauma atau tumor, abnormalitas status koagulasi kongenital atau didapat, malformasi arteri-vena, dan pasien dengan riwayat infeksi kronik atau akut ( $\leq 4$ minggu sebelum onset PISS).

Penegakan diagnosis PISS dilakukan pada pasien yang datang ke IGD RSCM dengan gejala klinis perdarahan intraparenkim spontan yang dikonfirmasi dengan CT scan cito. Indikasi operasi PISS adalah: (1) volume perdarahan antara 2080cc; (2) perburukan level kesadaran atau defisit neurologis; dan/atau (3) perdarahan superfisial/ lobaris. ${ }^{11}$ Pemeriksaan leukosit dilakukan pada saat datang sebelum operasi dan hari pertama pascaoperasi untuk kemudian dibandingkan antara keduanya.

Operasi yang dilakukan dapat berupa (1) kraniotomi evakuasi hematoma, yaitu tulang kranium dibuka, evakuasi hematoma, lalu tulang dikembalikan (2) kraniektomi dekompresi evakuasi hematoma, yaitu tulang kranium dibuka, disimpan di rongga abdomen dan tidak dikembalikan lagi pascaevakuasi hematoma, untuk membebaskan rongga intrakranial. Subjek dilakukan pemeriksaan CT scan pascaoperasi antara 3-7 hari pascaoperasi untuk menentukan persentase evakuasi hematoma. Rerata persentase terbaik evakuasi hematoma adalah $67 \%$ untuk memberikan luaran baik. ${ }^{3}$

Penentuan luaran menggunakan Glasgow Outcome Score (GOS) yang dinilai pada bulan ke-6 pascaoperasi dengan cara menghubungi subjek atau keluarganya via telepon atau melalui data rekam 
medis, yang dikategorikan sebagai: (1) mati; (2) vegetatif persisten, yaitu pasien tidak ada kontak, hanya ada respon refleks disertai periode bukanya mata spontan; (3) disabilitas berat, yaitu pasien dependen terhadap bantuan sehari-hari dari orang lain karena adanya disabilitas fisik dan/atau mental; (4) disabilitas sedang, yaitu pasien memiliki disabilitas seperti disfasia, hemiparesis, atau epilepsi dan/atau defisit dari memori atau kepribadian namun masih mampu untuk merawat dirinya sendiri, berbelanja, dan bepergian dengan transportasi publik, serta masih mungkin bekerja dengan pengaturan spesial; (5) disabilitas ringan atau pemulihan baik, yaitu pasien yang dapat kembali ke kehidupan normalnya dan bekerja walaupun belum sempurna seperti sebelum cedera. ${ }^{12}$

Setelah seluruh data terkumpul, subjek dibagi menjadi 2 kelompok, yaitu dengan kenaikan nilai leukosit dan penurunan nilai leukosit. Data diolah menggunakan program SPSS; dilakukan uji korelasi Pearson untuk mengetahui korelasi antara nilai leukosit praoperasi dengan usia dan GCS praoperasi, uji korelasi Spearman untuk mengetahui korelasi antara nilai leukosit praoperasi dengan volume hematoma dan lama rawat inap.

Uji korelasi Spearman juga digunakan untuk mengetahui korelasi antara perbedaan nilai leukosit pra- dan pascaoperasi dengan GOS 6 bulan. Uji one way ANOVA dilakukan untuk menilai hubungan antara nilai leukosit praoperasi dengan GOS 6 bulan. Uji Fisher exact untuk mengetahui perbedaan nilai leukosit dengan mortalitas serta persentase evakuasi hematoma pascaoperasi. Dilakukan juga analisis untuk melihat ketahanan hidup selama 6 bulan pascaoperasi.

\section{HASIL}

Didapatkan 30 subjek (Tabel 1) yang mayoritas laki-laki $(60 \%)$ dengan rerata usia $54 \pm 10,3$ tahun, rerata volume perdarahan 35,5 (25-60)cc, median lama rawat inap 13 (2-56) hari, serta rerata kadar leukosit praoperasi $15.333,3 \pm 5.109,6 \mathrm{cc}$ yang sedikit menurun pascaoperasi. Mayoritas subjek masuk dalam keadaan penurunan kesadaran [median GCS 10 (7-14)] yang mengalami perbaikan pascaoperasi
Tabel 1. Karakteristik Subjek Penelitian $(n=30)$

\begin{tabular}{|c|c|}
\hline Variabel & Hasil \\
\hline Usia [Tahun; Rerata \pm SB] & $54 \pm 10,3$ \\
\hline \multicolumn{2}{|l|}{ Jenis Kelamin [n(\%)] } \\
\hline - Laki-laki & $18(60)$ \\
\hline - Perempuan & $12(40)$ \\
\hline \multicolumn{2}{|l|}{ Jenis Operasi [n(\%)] } \\
\hline - Kraniotomi evakuasi hematom & $16(53,3)$ \\
\hline $\begin{array}{l}\text { Kraniektomi dekompresi } \\
\text { evakuasi hematom }\end{array}$ & $14(46,7)$ \\
\hline \multicolumn{2}{|l|}{ Persentase Evakuasi $\$$} \\
\hline - $\leq 67 \%$ & $6(20)$ \\
\hline - $>67 \%$ & $9(30)$ \\
\hline $\begin{array}{l}\text { - Tidak dilakukan CT scan } \\
\text { pascaoperasi }\end{array}$ & $15(50)$ \\
\hline $\begin{array}{l}\text { Volume Perdarahan [cc; Median } \\
\text { (Min-Maks)] }\end{array}$ & $35,5(25-60)$ \\
\hline - $\quad<30 \mathrm{cc}$ & $1(3)$ \\
\hline - $31-40 \mathrm{cc}$ & $19(63)$ \\
\hline - $41-50 \mathrm{cc}$ & $6(20)$ \\
\hline - $51-60 \mathrm{cc}$ & $4(13)$ \\
\hline $\begin{array}{l}\text { Leukosit Praoperasi } \quad[\mathrm{sel} / \mu \mathrm{L} \text {; } \\
\operatorname{Rerata} \pm \mathrm{SB}]\end{array}$ & $15333,3 \pm 5109,6$ \\
\hline $\begin{array}{l}\text { Leukosit Pascaoperasi }[\mathrm{sel} / \mu \mathrm{L} \text {; } \\
\operatorname{Rerata} \pm \mathrm{SB}]\end{array}$ & $15198,3 \pm 5126$ \\
\hline \multicolumn{2}{|l|}{ Perbedaan Nilai Leukosit [n(\%)] } \\
\hline - Kenaikan & $12(40)$ \\
\hline - Penurunan & $18(60)$ \\
\hline $\begin{array}{l}\text { GCS Praoperasi [Median } \\
\text { (Minimal-Maksimal)] }\end{array}$ & $10(7-14)$ \\
\hline - $\leq 8$ & $6(20)$ \\
\hline - $9-12$ & $18(60)$ \\
\hline - $\geq 13$ & $6(20)$ \\
\hline $\begin{array}{l}\text { GCS Pulang [Median (Min- } \\
\text { Maks)]* }\end{array}$ & $14(13-15)$ \\
\hline \multicolumn{2}{|l|}{ Glasgow Outcome Scale [n(\%)] } \\
\hline - Skor 1 & $12(40)$ \\
\hline - $\quad$ Skor 2 & $0(0)$ \\
\hline - Skor 3 & $4(13,3)$ \\
\hline - Skor 4 & $11(36,7)$ \\
\hline - Skor 5 & $3(10)$ \\
\hline $\begin{array}{l}\text { Lama Rawat Inap [Hari; Median } \\
\text { (Min-Maks)] }\end{array}$ & $13(2-56)$ \\
\hline \multicolumn{2}{|l|}{ Luaran $[n(\%)]$} \\
\hline - Meninggal & $12(40)$ \\
\hline - Hidup & $18(60)$ \\
\hline
\end{tabular}

*Hanya ada 18 data karena 12 data meninggal; hanya ada 15 data karena 15 lainnya tidak ada CT scan pascaoperasi; GCS: Glasgow Coma Scale; SB: simpangan baku. 
[median GCS 14 (13-15)]. Namun sebagian besar subjek (40\%) mengalami kematian pada 6 bulan pascaoperasi.

Dilakukan dua jenis tindakan operasi, yaitu kraniotomi evakuasi hematoma saja $(53,3 \%)$ dan sisanya evakuasi hematoma disertai kraniektomi dekompresi. Luaran berdasarkan GOS menunjukkan kebanyakan subjek meninggal atau skor 1 (40\%) dan disabilitas berat atau skor $3(13,3 \%)$ dan hanya 3 subjek (10\%) yang mengalami luaran terbaik atau skor 5.

Terdapat hubungan signifikan korelasi terbalik dengan kekuatan cukup ( $\left.\mathrm{r}_{\mathrm{s}}:-0,405, \mathrm{p}: 0,026\right)$ antara perbedaan nilai leukosit pascaoperasi dibandingkan praoperasi dengan GOS 6 bulan pascaoperasi (Tabel 2).

Tabel 2. Korelasi antara Perbedaan Nilai Leukosit Pra- dan Pascaoperasi dengan GOS $(n=30)$

\begin{tabular}{lcc}
\hline \multicolumn{1}{c}{ Variabel } & $\begin{array}{c}\text { Koefisien } \\
\text { Korelasi }\end{array}$ & GOS \\
\hline \multirow{2}{*}{ Perbedaan leukosit } & $\mathrm{r}_{\mathrm{s}}$ & $-0,405$ \\
pra- dan pascaoperasi & $\mathrm{p}$ & 0,026 \\
& $\mathrm{n}$ & 30 \\
\hline
\end{tabular}

$\mathrm{r}_{\mathrm{s}}$ : Koefisien korelasi Spearman; GOS: Glasgow Outcome Scale.

Terdapat hubungan signifikan korelasi terbalik dengan kekuatan cukup antara jumlah leukosit praoperasi dengan GCS praoperasi ( $\mathrm{r}$ : $:-0,475, \mathrm{p}: 0,008)$ (Tabel 3).

\section{PEMBAHASAN}

Penelitian ini mayoritas subjek adalah lakilaki $(60 \%)$ dengan rerata usia $54 \pm 10,3$ tahun, sesuai dengan penelitian Chung dkk di Taipei, yaitu pasien PISS yang menjalani operasi laki-laki lebih banyak dibandingkan perempuan ( $62,5 \%$ vs $37,5 \%)$ dengan usia rata-rata 61,5 tahun. ${ }^{3}$ Demikian pula Kim dkk mendapatkan pasien laki-laki lebih banyak dibandingkan perempuan ( $56 \%$ vs $54 \%$ ) dengan usia rata-rata 60,3 tahun. ${ }^{13}$

Median lama rawat inap subjek penelitian ini adalah 13 (2-56) hari, dan ada 1 pasien yang meninggal pada saat 2 hari perawatan. Hasil ini lebih pendek dibandingkan Chung dkk dan Kim dkk, yaitu rerata lama rawat inap pasien yang menjalani operasi adalah 28,35 hari $^{3}$ dan $20,33 \pm 6,37$ hari. $^{13}$

Tabel 4. Hubungan antara Kadar Leukosit Praoperasi dan Pascaoperasi dengan Skor GOS $(n=30)$

\begin{tabular}{lc}
\hline Kadar Leukosit & Skor GOS \\
\hline Praoperasi & $0,916^{*}$ \\
Pascaoperasi & $0,715^{*}$ \\
\hline *Uji Annova; GOS: Glasgow Outcome Scale. &
\end{tabular}

Mayoritas subjek masuk dalam keadaan penurunan kesadaran [median GCS 10 (7-14)] yang mengalami perbaikan pascaoperasi [median GCS 14 (13-15)]. Hal ini menunjukkan bahwa tindakan operasi evakuasi hematoma ataupun disertai

Tabel 3. Korelasi antara Nilai Leukosit Praoperasi dengan Usia, GCS Praoperasi, Lama Rawat Inap, dan Volume Perdarahan $(n=30)$

\begin{tabular}{lcccccc}
\hline \multicolumn{1}{c}{ Variabel } & $\begin{array}{c}\text { Koefisien } \\
\text { Korelasi }\end{array}$ & Usia & $\begin{array}{c}\text { Koefisien } \\
\text { Korelasi }\end{array}$ & $\begin{array}{c}\text { GCS } \\
\text { Praoperasi }\end{array}$ & $\begin{array}{c}\text { Lama Rawat } \\
\text { Inap }\end{array}$ & $\begin{array}{c}\text { Volume } \\
\text { Perdarahan }\end{array}$ \\
\hline Leukosit & $\mathrm{r}$ & $-0,190$ & $\mathrm{r}$ & $-0,475$ & $-0,051$ & $-0,170$ \\
Praoperasi & $\mathrm{p}$ & 0,314 & $\mathrm{p}$ & 0,008 & 0,788 & 0,270 \\
& $\mathrm{n}$ & 30 & $\mathrm{n}$ & 30 & 30 & 30 \\
\hline r: Koefisien korelasi Pearson; $\mathrm{r}$ : Koefisien korelasi Spearman; GCS: Glasgow Coma Scale. & &
\end{tabular}

Tidak terdapat hubungan yang signifikan antara nilai leukosit praoperasi dengan GOS 6 bulan pascaoperasi (p:0,916), usia (r:-0,910, p:0,314), volume perdarahan $\left(\mathrm{r}_{\mathrm{s}}: 0,170, \mathrm{p}: 0,270\right)$, dan lama rawat inap ( $\left.\mathrm{r}_{\mathrm{s}}:-0,051, \mathrm{p}: 0,788\right)$ (Tabel 3 dan 4$)$.

Demikian pula tidak didapatkan hubungan yang bermakna antara perbedaan nilai leukosit pradan pascaoperasi dengan mortalitas dalam 6 bulan (p:0,458) dan dengan persentase evakuasi hematoma pascaoperasi (p:0,085) (Tabel 5). dekompresi dapat memperbaiki kesadaran pasien dengan PISS.

Namun sebagian besar subjek (40\%) mengalami kematian pada 6 bulan pascaoperasi. Angka morbiditas dan mortalitas memang dapat meningkat pada PISS, baik dioperasi ataupun tidak. Agnihotri dalam penelitiannya menyebutkan angka kematian pasien PISS dalam 1 tahun adalah sebesar 45,2 \%. ${ }^{4}$ Etminan menjelaskan kasus fatalitas PISS pada 7 hari 
Tabel 5. Hubungan antara Perbedaan Nilai Leukosit dengan Mortalitas dan \% Evakuasi Hematoma Pascaoperasi $(\mathbf{n}=\mathbf{3 0})$

\begin{tabular}{lcc}
\multicolumn{1}{c}{ Variabel } & $\begin{array}{c}\text { Mortalitas } \\
\text { (Hidup, Meninggal) }\end{array}$ & $\begin{array}{c}\text { \% Evakuasi Hematoma } \\
\text { Pascaoperasi }\end{array}$ \\
\hline $\begin{array}{l}\text { Perbedaan nilai leukosit pra- dan } \\
\text { pascaoperasi }\end{array}$ & $0,458^{*}$ & $0,085^{*}$ \\
\hline *Uji Fisher exact test. & &
\end{tabular}

*Uji Fisher exact test.

sebanyak 31\% dan 1 tahun sebanyak 59\%. ${ }^{11} \mathrm{Hal}$ ini dapat disebabkan oleh perdarahan ulang, kejadian yang berhubungan dengan kardiologi, infeksi paru, gangguan organ lain, dan sebab lain yang tidak diketahui. ${ }^{13}$

Hasil penelitian yang ada menunjukkan semakin tinggi selisih nilai leukosit maka GOS akan menurun dalam 6 bulan pascaoperasi. Semakin besar kenaikan atau penurunan nilai leukosit pascaoperasi, maka luaran klinis akan semakin buruk. Hal ini sejalan dengan penelitian kasus PISS yang tidak dioperasi oleh Agnihotri dkk, bahwa perbedaan hitung leukosit yang lebih tinggi dalam 72 jam pertama pasca-awitan diasosiasikan dengan luaran jangka pendek dan jangka panjang yang buruk. ${ }^{4}$

Proses inflamasi umum terjadi pada PISS. Terdapat berbagai macam tipe sitokin yang berperan dalam proses tersebut, baik yang bersifat pro atau antiinflamasi. Ketika terjadi proses inflamasi yang hebat dan berlebihan, respons yang terjadi adalah kenaikan sitokin pro-inflamasi yang sangat tinggi dibandingkan dengan praoperasi. ${ }^{5}$

Hal kedua yang dapat juga terjadi saat terjadi proses inflamasi yang hebat dan berlebihan adalah adanya regulasi sistem imun yang tidak normal yang ditandai dengan penurunan nilai leukosit yang lebih rendah. Sebuah penelitian mengenai ukuran hematoma sebagai modulator mayor dari sistem imun seluler pasca-eksperimental perdarahan intraserebral spontan yang tidak dioperasi pada hewan coba menyebutkan bahwa pada hematoma berukuran besar, didapatkan adanya limfositopenia, leukopenia, dan monositosis. ${ }^{8}$

Subjek penelitian ini mengalami sedikit penurunan leukosit pascaoperasi yang dapat disebabkan oleh ukuran hematoma praoperasi. Semakin besar ukuran hematoma, akan semakin rendah nilai leukosit pascaoperasi, akibat hilangnya regulasi imunitas normal. Subjek penelitian ini memiliki ukuran yang besar sesuai dengan indikasi operasi perdarahan intraserebral spontan. ${ }^{14}$

Pada penelitian ini terdapat subjek yang mengalami kenaikan dan ada yang mengalami penurunan nilai leukosit pascaoperasi dibandingkan praoperasi. Namun secara umum terdapat peningkatan rerata kadar leukosit praoperasi, yaitu $15.333,3 \pm 5.109,6 \mathrm{cc}$. Kenaikan nilai leukosit pada hari pertama pascaoperasi dapat disebabkan oleh masih adanya hematoma dalam volume yang cukup signifikan dibandingkan dengan sisa hematoma subjek yang mengalami penurunan nilai leukosit, sehingga kaskade inflamasi relatif masih berlangsung dan menyebabkan kenaikan nilai leukosit di hari pertama pascaoperasi. Kenaikan leukosit di hari pertama pascaoperasi ini kemungkinan bukan disebabkan oleh infeksi, dikarenakan infeksi praoperasi telah menjadi kriteria eksklusi.

Berdasarkan penelitian sebelumnya mengenai PISS yang tidak dioperasi, baik pada hewan coba atau pada manusia, proses inflamasi dapat segera terjadi bahkan sejak 1 jam pasca-awitan PISS. Hal ini menjadi penanda bahwa leukositosis praoperasi merupakan indikator proses inflamasi telah dimulai dan berlangsung, dengan infeksi menjadi salah satu kriteria eksklusi subjek penelitian ini. . $^{315-16}$

Operasi evakuasi hematoma dapat mencegah berlanjutnya proses inflamasi yang terjadi sebelum mencapai puncaknya, pada 72 jam atau 3 hari pascaonset. Efek cedera otak primer dikurangi dengan cara evakuasi hematoma sehingga efek desak ruang terhadap jaringan otak normal diminimalisasikan, dan tekanan intrakranial turun. Hal ini juga akan menurunkan efek cedera otak sekunder akibat hematoma (produk darah) sebelum proses inflamasi mencapai puncaknya, sehingga kerusakan lebih berlanjut dari jaringan otak dapat dicegah. 
Inflamasi juga dapat disebabkan oleh proses operasi tersebut sendiri, akibat kerusakan jaringan pada proses insisi, kraniotomi, diseksi jaringan, maupun kortikotomi. Penelitian Agrawal dkk yang mempelajari leukositosis pada tumor serebri intraaksial yang dilakukan kraniotomi removal tumor dan aneurisma serebral yang dilakukan kraniotomi clipping aneurisma menunjukkan bahwa terjadi kenaikan nilai leukosit pada hari pertama pascaoperasi dibandingkan leukosit praoperasi dengan rasio yang bervariasi akibat kerusakan jaringan parenkim otak. ${ }^{17}$ Pada penelitian ini, prosedur operasi dianggap memberikan proses inflamasi yang homogen, sejalan dengan penelitian lain bahwa tidak ada perbedaan antara prosedur kraniotomi ataupun kraniektomi evakuasi hematoma pada PISS. ${ }^{18}$

Penelitian ini menunjukkan adanya korelasi terbalik berkekuatan cukup antara nilai leukosit praoperasi dengan Glasgow Coma Scale (GCS) praoperasi, yaitu semakin tinggi nilai leukosit praoperasi, semakin rendah GCS praoperasi (Gambar 1). Hal ini selaras dengan Behrouz dkk, adanya hubungan terbalik antara nilai leukosit dengan GCS saat admisi pasien PISS yang tidak dioperasi. Pasien dengan GCS admisi yang lebih rendah akan memiliki nilai hitung leukosit kurang dari 24 jam yang lebih tinggi. ${ }^{14,19}$ Pada PISS yang tidak dioperasi, leukosit yang semakin tinggi menggambarkan semakin hebatnya derajat inflamasi, sehingga efek cedera otak primer dan sekunder juga semakin berat. Hal ini yang menyebabkan kesadaran pasien lebih rendah.

Kesintasan 6 bulan pasien PISS yang dioperasi pada penelitian ini yang mengalami penurunan jumlah leukosit akan memiliki survival-rate yang lebih tinggi dibandingkan kelompok subjek yang mengalami kenaikan jumlah leukosit. Angka ketahanan 6 bulan
(6 months-survival rate) penelitian ini adalah sebesar 65\%. Angka ini hampir sama dibandingkan Lopponen dkk yang didapatkan survival rate 3 bulan sebesar $66 \%$ pada pasien PISS yang tidak dioperasi, serta Tae Kim dkk yang mendapatkan 3 months-survival rate sebesar $85,2 \%$ pada pasien PISS yang dioperasi. ${ }^{13,18}$

Angka kesintasan penelitian ini lebih rendah kemungkinan karena diukur dalam 6 bulan pascaoperasi, dibandingkan dengan kedua penelitian lain yang diukur dalam 3 bulan pasca-awitan, karena bisa saja terdapat peningkatan morbiditas dan mortalitas seiring berjalannya waktu pasca-awitan PISS. Angka ini memang tidak dapat dibandingkan secara langsung mengingat adanya perbedaan antara jangka waktu pengukuran 3 bulan pada kedua penelitian lain dibandingkan dengan 6 bulan pada penelitian ini.

Penelitian ini memiliki beberapa kelemahan, diantaranya adalah jumlah sampel yang sedikit, bentuk studi retrospektif, dan luaran yang menggunakan satu parameter. Peneliti menyarankan parameter luaran dapat ditambahkan seperti modified Rankin Scale dan penilaian luaran dalam rentang waktu yang berbeda seperti 7 hari, 1 bulan, 3 bulan, dan 6 bulan pascaoperasi agar dapat melihat tren luaran dikaitkan dengan waktu.

\section{KESIMPULAN}

Perbedaan nilai leukosit pra- dan pascaoperasi dapat dipertimbangkan untuk digunakan sebagai salah satu faktor prognostik luaran klinis yang dinilai dengan GOS 6 bulan pascaoperasi pada pasien PISS. Semakin tinggi selisih nilai leukosit, akan semakin rendah skor GOS. Namun nilai leukosit praoperasi saja tidak dapat dijadikan sebagai prediktor luaran klinis pasien PISS yang dioperasi.

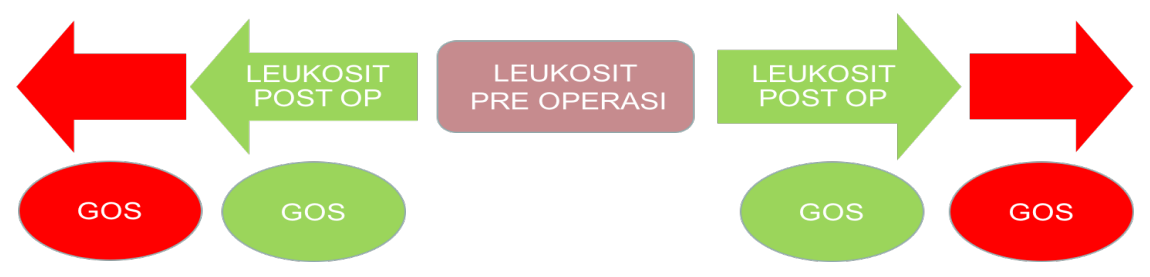

Gambar 1. Korelasi antara Perbedaan Nilai Leukosit Pra- dan Pascaoperasi dengan Glasgow Outcome Scale (GOS) 6 Bulan Pascaoperasi 


\section{DAFTAR PUSTAKA}

1. Maya DM, Margarita LA, Nachko IT, Irena IG, Plamen GS. Clinical and neuroimaging studies in patients with acute spontaneous intracerebral hemorrhage. IMAB. 2014;20(2):489-94.

2. Dreden P, Hue G, Dreyfus J, Woodhams B, Vasse M. Procoagulant phospholipids and tissue factor activity in cerebrospinal fluid from patients with intracerebral haemorrhage. Advances in Hematology. 2014;2014:576750.

3. Tsao Chung T, Hsieh C, Chen Y, Chang C. Effects of hematoma reduction by stereotactic aspiration for patients with spontaneous intracerebral hemorrhage. Neurosurg Q. 2015:25(1):17-23.

4. Agnihotri S, Czap A, Staff I, Fortunato G, McCullough L. Peripheral leukocyte counts and outcomes after intracerebral hemorrhage. J Neuroinflammation. 2011;8:160.

5. Mracsko E, Veltkamp R. Neuroinflammation after intracerebral hemorrhage. Front Cell Neurosci. 2014;8;388.

6. Morotti A, Phuah C, Anderson C, Jessel M, Schwab $\mathrm{K}$, Ayres A, dkk. Leukocyte count and intracerebral hemorrhage expansion. Stroke. 2016;47(6):1473-8.

7. Fu X, Wong KS, Wei JW, Chen X, Lin Y, Zeng J. Factors associated with severity on admission and in-hospital mortality after primary intracerebral hemorrhage in China. Int J Stroke. 2013;8(2)73-9.

8. Rodriguez J, Sobrino T, Arias EL, Ugarte A, SanchezArias J, Vieites-Prado A, dkk. CM352 reduces brain damage and improves functional recovery in a rat model of intracerebral hemorrhage. J Am Heart Assoc. 2017;6(6):e006042.

9. Specogna A, Turin T, Patten S, Hill M. Factors associated with early deterioration after spontaneous intracerebral hemorrhage: a systematic review and meta-analysis. PloS One. 2014:9(5)e96743.

10. Szepesi R, Szell IK, Hortobagyi T, Kardos L,
Nagy K, Lanczi L, dkk. New prognostic score for the prediction of 30-day outcome in spontaneous supratentorial cerebral haemorrhage. Biomed Res Int. 2015;2015:961085.

11. Etminan N, Beseoglu K, Hanggi D. Neurosurgery in hemorrhagic stroke. Panvascular Medicine. 2015;1:2799-821.

12. Dagher J, Costa C, Lamoureux J, Guise E, Feyz M. Comparative outcomes of traumatic Brain injury from biking accidents with or without helmet use. Can J Neurol Sci. 2016;43(1):56-64.

13. Mrascko E, Veltkamp R. Neuroinflammation after intracerebral hemorrhage. 2014. Front Cell Neurosci. 2014;8:388.

14. Wang J. Preclinical and clinical research on inflammation after intracerebral hemorrhage. Prog Neurobiol. 2010;92:463-77.

15. Liesz A, Purrucker J, Ruger H, Zorn M. Stress mediators and immune dysfunction in patients with acute cerebrovascular diseases. PloS One. 2013;8(9):e74839.

16. Agrawal D, Kurwale N. Leukocytosis after routine cranial surgery: a potential marker for brain damage in intracranial surgery. Asian J Neurosurg. 2016;11(2):109-13.

17. Lopponen P, Qian C, Tetri S, Juvela S, Huhtakangas $\mathrm{J}$, Bode M, dkk. Predictive value of C-reactive protein for the outcome after primary intracerebral hemorrhage. J Neurosurg. 2014;121(6):1374-9.

18. Behrouz R, Hafeez S, Miller CM. Admission leukocytosis in intracerebral hemorrhage: associated factors and prognostic implications. Neurocrit Care. 2015;23(3):370-3.

19. Kim H, Jong M, Koh E, Choi H. Surgery versus conservative treatment for spontaneous supratentorial intracerebral hemorrhage in spot sign positive patients. J Korean Neurosurg Soc. 2015;58(4):30915. 